\title{
TWILIGHT ON THE RANGE \\ Recollections of a Latterday Cowboy
}


THIS PAGE INTENTIONALLY LEFT BLANK 
Number Two

THE M. K. BROWN RANGE LIFE SERIES 
THIS PAGE INTENTIONALLY LEFT BLANK 


\section{William Timmons}

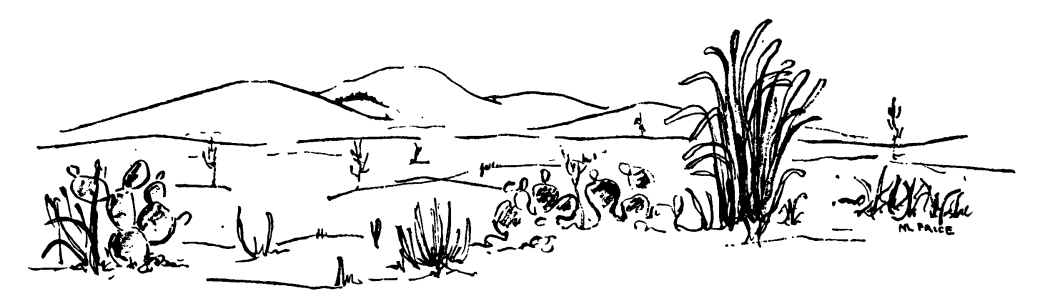

\section{TWILIGHT ON THE RANGE}

Recollections of a Latterday Cowboy

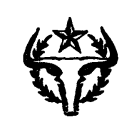

UNIVERSITY OF TEXAS PRESS • AUSTIN 
Library of Congress Catalog Card No. 61-13317 Copyright (C) 1962 by the University of Texas Press All Rights Reserved

Manufactured in the United States of America by the Printing Division of the University of Texas ISBN 978-0-292-76605-1 (library e-book) ISBN 978-0-292-76606-8 (individual e-book) 
To

my wife,

LORA

and daughters,

LuCILle LiLliaN

and granddaughters,

SusaN

Connie 
THIS PAGE INTENTIONALLY LEFT BLANK 